\title{
Menulis Cerpen Bermuatan nilai Karakter dengan Media Film Keluarga
}

\author{
Yusni Anisa $^{1}$, Wahyudi Siswanto ${ }^{1}$, Yuni Pratiwi ${ }^{1}$ \\ ${ }^{1}$ Pendidikan Bahasa Indonesia-Universitas Negeri Malang
}

\section{INFO ARTIKEL}

\section{Riwayat Artikel:}

Diterima: 11-09-2019

Disetujui: $19-03-2020$

\section{Kata kunci:}

writing short stories;

character value;

family film;

menulis cerpen;

nilai karakter;

film keluarga

\author{
Alamat Korespondensi: \\ Yusni Anisa \\ Pendidikan Bahasa Indonesia \\ Universitas Negeri Malang \\ Jalan Semarang 5 Malang \\ E-mail: yusnianisa94@gmail.com
}

\section{ABSTRAK}

Abstract: This development research aims to produce a product in the form of teaching materials for writing short stories containing character values through family film media for class XI students and producing supplementary guidelines for using short story writing teaching materials for teachers and students. This development research model uses the 4D development model which consists of four steps, viz define, design, development, and disseminate. Validation test results of expert and practitioners in terms of content, presentation, language, and appereance with qualifications worth implementing. Effectiveness test results are normally distributed $>0.05$ and the significance obtained is $0.00<005$.

\begin{abstract}
Abstrak: Penelitian ini bertujuan untuk menghasilkan produk bahan ajar menulis cerpen bernilai karakter melalui media film keluarga untuk siswa SMA kelas XI dan menghasilkan panduan pelengkap penggunaan produk bahan ajar menulis cerpen bagi guru dan siswa. Model penelitian yang digunakan adalah model pengembangan 4D (four $D$ model) terdiri atas empat langkah, yaitu define, design, development, dan disseminate. Hasil uji validasi ahli dan praktisi dari segi isi, penyajian, bahasa, dan tampilan dengan kualifikasi layak diimplementasikan. Hasil uji keefektifan terdistribusi normal $>0,05$ dan signifikansi yang diperoleh sebesar $0,00<005$.
\end{abstract}

Pengembangan buku ajar yang efektif bisa memudahkan peserta didik dalam meningkatkan kompetensi pengetahuan, sikap, dan keterampilan. Peningkatan kualitas bahan ajar perlu dilakukan secara berkelanjutan di sekolah. Kegiatan yang bisa dilaksanakan yaitu menciptakan bahan/buku ajar yang baik dan menarik, sehingga pengetahuan siswa dalam mempelajari penulisan cerpen menjadi bertambah. Bahan ajar yang berkualitas memiliki kontribusi yang besar terhadap keberhasilan proses pembelajaran. Mengembangkan bahan/buku teks ajar adalah suatu kegiatan yang perlu dilaksanakan sebagai penopang dalam proses pembelajaran, olehnya itu mengembangkan bahan/buku teks ajar dengan prosedur yang baik perlu diterapkan. Memilih dan Menyajikanan bahan/buku tejs ajar mata pelajaran Bahasa dan Sastra Indonesia perlu memenuhi dua kriteria, yakni kriteria umum (kriteria yang berlaku untuk semua mata pelajaran) dan kriteria khusus (kriteria yang hanya berlaku untuk mata pelajaran bahasa dan sastra Indonesia) (Romansyah, 2016).

Sastra menjadi salah satu dokumen penting yang mengabadikan buah pikiran leluhur yang mengharapkan generasi berikutnya mendapatkan kehidupan yang lebih baik dan mulia (Herawan \& Sudarsana, 2017). Salah satu kompetensi yang dikembangkan dalam diri peserta didik yakni kompetensi menulis cerpen. Pembelajaran menulis cerita pendek bertujuan agar peserta didik dapat mengekspresikan ide, dan imajinasinya. Peranan guru bahasa Indonesia pada tahap ini adalah sebagai motivator dan pembimbing agar siswa gemar menulis cerpen. Cerpen yang baik adalah cerpen yang memiliki kemampuan untuk menunjukkan gejala masyarakat pada saat tertentu, pandangan dunia, sistem sosial, sistem budaya, bahkan juga menampilkan adanya kecenderungan ilmu pengetahuan (Kusumarini, 2013).

Pembelajaran menulis cerpen merupakan kegiatan yang kompleks. Kegiatan tersebut membutuhkan ide yang kreatif, bernilai estetika sastra, dan bahasa yang digunakan bersifat komunikatif. Dalam proses penulisan cerpen juga diperlukan kemampuan berimajinasi yang tinggi. Semua ide hanya bermunculan di kepala, didiamkan, dan diketahui sendiri, tetapi tidak dapat diwujudkan dalam bentuk tulisan yang dapat dibaca banyak orang. Padahal, tidak ada satu bidang pun di dunia ini yang dapat lepas dari tulis menulis, salah satunya menulis cerpen (Aeni \& Lestari, 2018). (Bird, 2001) menyatakan bahwa teknik menulis fiksi dapat diajarkan. Jadi, kemampuan menulis bukanlah merupakan bakat semata atau sesuatu yang langsung dikirim oleh Tuhan tanpa harus dipelajari dan diajarkan. Aspek penting yang lain, yakni penggunaan bahasa yang efektif, menghibur, berkarakter, menginspirasi, dan lainnya. Berdasarkan pengamatan di beberapa sekolah, kegiatan pembelajaran menulis cerpen belum tercipta dalam suasana yang kreatif sehingga kreativitas siswa belum berimbang dengan optimal. Faktor penyebabnya 
adalah bahan ajar tidak memadai, guru kurang kreatif memilih media pembelajaran yang mampu mengembangkan kreativitas siswa. Misalnya, ketika mengajarkan materi menulis cerpen, guru hanya membacakan cerpen kemudian siswa disuruh menyimak, selanjutnya siswa menuliskan kembali cerita pendek yang telah diperdengarkan tanpa memberi bimbingan dan tahapan-tahapan dalam proses menulis. Selain itu, tidak ada media yang digunakan agar memudahkan siswa dalam menulis.

Sekarang ini, bangsa Indonesia sedang mengalami kekurangan nilai karakter, hal itu ditandai dengan semakin maraknya kejahatan dan perlakuan-perlakuan lain yang kurang mencerminkan nilai karakter bangsa, yang dilakukan oleh manusia terdidik dan memiliki posisi/jabatan penting dalam pemerintahan atau kemasyarakatan (Ghufron, 2010). Penanaman nilai karakter pada siswa sebagai sebuah karakteristik seseorang sebenarnya bukan sesuatu yang baru. Namun, seiring dengan perkembangan globalisasi, nilai karakter mulai terkikis sehingga penanaman kembali nilai tersebut ke dalam sebuah wadah kegiatan pendidikan di setiap pengajaran harus dilakukan. Diyakini bahwa implementasi pendidikan karakter sangat dipengaruhi oleh lingkungan pendidikan (Ramdhani, 2014). Pendidikan karakter adalah proses menuntun siswa untuk menjadi manusia seutuhnya yang berkarakter dalam dimensi hati, pikiran, raga, serta rasa, dan karsa (Samani \& Hariyanto, 2013). Nilai karakter tersebut diimplementasikan dalam isi bahan ajar menulis cerpen agar terbentuk sebuah karakter yang handal.

Sehubungan dengan tuntutan yang diharapkan kurikulum dan dari permasalahan yang terdapat di sekolah yang berhubungan dengan pembelajaran menulis cerpen, diperlukan adanya suatu media yang dapat membangkitkan kreativitas siswa. Pembelajaran menulis cerita pendek dengan model kreatif-produktif lebih tepat diberlakukan pada siswa bertipe penginderaan daripada intuisi (Mubaroq \& Subyantoro, 2017). Media yang dipilih adalah media film keluarga, media ini diharapkan dapat mengurangi kesulitan siswa dalam prsoses menulis cerpen.

Hadirnya media film keluarga dalam kegiatan pembelajaran yang ditayangkan nantinya diharapkan menjadi sumber inspirasi dalam menulis cerpen. Film keluarga diharapkan dapat dijadikan inspirasi penentuan tema, tokoh, alur, setting, serta unsur lainnya dalam menulis cerpen. Keuntungan belajar menggunakan media film yang meningkatkan daya imajinasi siswa dalam menulis, dapat memberikan suatu pengaruh yang sesuai dengan tujuan. Respons yang diharapkan oleh peserta didik terkait dalam menulis cerpen dapat menumbuhkan minat dan motivasi siswa dalam menulis, serta memengaruhi emosi siswa.

Sesuai dengan kurikulum, proses belajar menulis cerita pendek diajarkan kepada peserta didik di SMA kelas XI. Sebagian besar siswa yang berada pada masa peralihan dari remaja menjadi dewasa dengan umur yang memasuki 17 tahun. Pada umur tersebut, nilai-nilai karakter perlu ditanamkan kembali dalam kegiatan belajar. Adapun kegunaan dilakukannya penelitian ini adalah untuk menciptkan produk yakni buku ajar menulis cerpen bernilai karakter dengan media film keluarga untuk siswa SMA kelas XI dan menghasilkan panduan pelengkap penggunaan produk bahan ajar menulis cerpen bagi guru dan siswa.

\section{METODE}

Penelitian pengembangan ini dilakukan dengan model pengembangan 4D (four D model) oleh (Thiagarajaan, 1974) yaitu define, design, development, dan disseminate. Keempat tahap tersebut yaitu, pendefinisian, perancangan, pengembangan, dan penyebarluasan. Pengguaan model 4D dipilih karena sesuai dengan tujuan penelitian dengan menghasilkan produk bahan ajar yang memerlukan kesistematisan dalam pengembangannya. (1) Pendefinisian. Pada tahap ini berguna untuk mengetahui apa saja yang diperlukan dalam kegiatan belajar. Hal yang dilakukan adalah menganalisis keperluan berkaitan dengan tuntutan kurikulum, analisis kebutuhan siswa, analisis topik, serta analisis tujuan pembelajaran.

Pada proses pendefinisian ini dilaksanakan observasi dengan mewawancarai guru mata palajaran bahasa Indonesia untuk mengetahui kesulitan belajar siswa dan kendala guru dalam pembelajaran. (2) Perancangan. Perancangan mencakup segala hal yang berkaitan dengan persiapan dalam mengembangkan produk bahan ajar menulis cerpen. Rancangan produk isi disusun dengan memerhatikan karakteristik bahan ajar sesuai dengan ketentuan dari BSNP dan karakteristik penulisan cerpen, sedangkan rancangan produk penyajian dengan memerhatikan desain bahan ajar dan kurikulum. (3) Pengembangan. Pada tahap ini, format produk awal dikembangkan sesuai dengan perencanaan yang telah dibuat mulai dari pengembangan bagian penyajian bahan ajar sampai dengan pengembangan isi bahan/buku ajar kemudian diujicobakan melaui tim validator. Tugas validator yakni memvalidasi materi menulis cerpen dan memberikan saran terkait isi yang ada di bahan/buku ajar.

Selain itu, terdapat validator ahli desain untuk memberikan masukan terkait penyajian produk bahan ajar yang mencakup penampilan luar dan dalam dari produk. Setelah mendapatkan masukan dari tim validator, bahan ajar perlu direvisi untuk memperbaiki dan melengkapi kekurangan. Perbaikan diperlukan guna menghasilkan produk bahan ajar menulis cerpen yang bisa mempermudah praktisi/guru dan siswa dalam pembelajaran. Produk yang direvisi mulai dari penyajian, desain produk, materi, dan isi keseluruhan produk bahan ajar menulis cerpen. Pada tahap uji coba lapangan yakni siswa SMA kelas XI sesuai dengan materi yang diajarkan. Uji coba dilakukan agar mengetahui kemungkinan adanya kendala dalam proses pembelajaran penggunaan bahan ajar menulis cerpen. (4) Penyebarluasan. Pada tahap ini dilakukan pengemasan dan penyebaran. Produk bahan ajar dikemas dalam bentuk cetak kemudian disebarluaskan dengan cara menggandakan produk untuk disebarkan di sekolah tempat uji, perpustakaan, dan tempat lainnya. 
Dalam proses pengembangan untuk uji validasi, peneliti melibatkan tim ahli pembelajaran cerpen dan ahli menulis kreatif cerpen sebagai validator instrumen pada produk yang dikembangkan untuk menguji kelayakan dan keefektifan produk. Uji ahli pembelajaran cerpen adalah yang memiliki wawasan dan pengetahuan mengenai teori-teori pembelajaran cerpen. Ahli menulis kreatif cerpen adalah ahli yang memiliki wawasan dan pengetahuan tentang teori-teori yang terkait dengan penulisan kreatif cerita pendek. Ahli praktisi adalah guru yang mengajar dalam bidang mata pelajaran bahasa Indonesia.

Data dan sumber data yang dihasilkan berupa data penelitian pengembangan hasil validasi tim ahli, praktisi, serta hasil uji keefektifan produk. Sumber data yang didapat dari penilaian angket pada instrumen pengumpulan data dari tim ahli, praktisi, dan lapangan. Angket yang digunakan adalah angket tertutup untuk mengetahui kelayakan produk dari segi isi, penyajian, bahasa, dan tampilan dari setiap skor yang diperoleh. Dalam menganalisis data dilakukan pada penelitian pengembangan ini, yakni analisis data verbal serta analisis data berupa angka. Analisis data verbal diperoleh dari saran dan masukan tim ahli dan praktisi. Analisis data berupa angka diperoleh dari pengumpulan hasil peroleh penilaian skor angka dari angket instrumen dengan hasil yang disesuaikan dengan simpulan validasi dalam bentuk persentase.

Uji keefektifan produk dilaksanakan agar dapat mengetahui pengaruh produk bahan ajar yang menggunakan media film keluarga efektif digunakan untuk siswa menulis cerpen bermuatan nilai karakter yang dilakukan dengan uji praeksperimen pada satu kelompok kelas XI SMA Negeri 8 Malang. Uji praeksperimen terdapat uji pretest dan uji postest. Hasil uji pretest dan postest dilihat perbandingan hasil pengaruh sebelum produk diimplementasikan dengan sesudah produk diimplementasikan.

\section{HASIL}

Hasil penelitian pengembangan ini dilakukan dengan deskripsi produk. Produk yang dihasilkan ialah Bahan Ajar Menulis Cerpen Bermuatan Nilai Karakter dengan Media Film Keluarga untuk Siswa SMA Kelas XI. Produk ini dapat digunakan guru sebagai penunjang dari buku teks/buku ajar yang digunakan di sekolah, sedangkan bagi peserta didik sebagai penunjang pembelajaran bahasa Indonesia. Bahan ajar ini dilengkapi dengan dengan materi, latihan, serta tahapan mengembangkan unsur intrinsik teks cerpen.

Berdasarkan kompetensi yang ingin dicapai, isi buku ini terdiri dari (1) teori, contoh, dan latihan yang berisi pokokpokok pembelajaran yang dipelajari selama proses belajar mengajar (2) langkah-langkah menulis cerpen. Pertama, materi bahan/buku ajar bertujuan untuk memudahkan siswa dalam memahami cerpen. Pada bagian materi disajikan pemahaman awal mengenai cerpen yang bernilai karakter. Materi yang ditentukan teresebut harus memiliki keterkaitan sesuai kebutuhan belajar dan psikologi siswa untuk mencapai indikator pembelajaran (Andayani, Pratiwi, \& Priyatni, 2017). Materi dibuat dengan menggunakan kebahasaan yang simpel dan mudah dicerna oleh siswa. Contoh dicantumkan pada setiap materi yang diberikan dalam pembelajaran yang berguna untuk memudahkan siswa dalam mencerna maksud dari penjelasan materi tersebut. Pada contoh dilengkapi dengan warna yang berbeda untuk mempermudah peserta didik dalam memahami contoh tersebut. Latihan ditugaskan kepada siswa bertujuan mempermudah mereka untuk memahami materi dan meningkatkan penguasaan terhadap materi yang diberikan oleh pendidik. Latihan yang dituangkan pada unit 1 beragam, berbeda dengan latihan pada unit 2 . Latihan yang yang diberikan dengan jawaban esai dari peserta didik berkaitan dengan unsur-unsur intrinsik tentang cerpen yang bermuatan nilai karakter yang akan ditulis.

Kedua, langkah-langkah menulis cerpen. Bahan ajar menulis cerpen ini disusun secara terstruktur dan bertahap. Hal ini disebabkan kegiatan pembelajaran diawali dengan pemahaman unsur cerita pendek dengan menggunakan teks cerpen dan pengayaan media film pada unit 1 dan dilanjutkan dengan mencipta atau menulis cerpen dengan menggunakan media film pada unit 2, kegiatan tersebut dilakukan agar peserta didik tidak terlalu kesulitan dalam menulis cerpen bermuatan nilai karakter. Siswa senang belajar dengan menonton, kreatif, bagus, lebih mudah memahami, menghilangkan kebosanan, mengasyikkan, dapat belajar langsung, dan siswa yang mulanya malas belajar menjadi tertarik (Wahyuni, 2015).

Pada unit 1 peserta didik diberikan pemahaman mengenai unsur cerita pendek dengan pengayaan media film yang di dalamnya terdapat subpokok mengidentifikasi isi cerpen, menemukan tema, menentukan tokoh dan penokohan, menemukan alur dan latar cerpen, mengidentifikasi sudut pandang, dan mengidentifikasi gaya bahasa. Pada unit 2 peserta didik diberikan tugas untuk menulis cerita pendek bernilai karakter dengan media film yang di dalamnya terdapat subpokok mengembangkan tema cerpen bermuatan nilai karakter, menentukan tokoh, menetukan penokohan, menentukan latar, menentukan sudut pandang, dan menentukan gaya bahasa, dan mengembangkan alur kemudian menulis cerpen secara utuh. Setelah itu siswa dituntut melakukan penilaian teman sejawat, menyunting dan merevisi kemudian memublikasikan cerpen bermuatan nilai karakter di majalah dinding sekolah. Majalah dinding dapat menjadi media tulis dalam komunikasi antara siswa dan guru, atau sebaliknya (Dewi, 2013).

Aspek penyajian adalah aspek penting dalam penyusunan bahan teks ajar. Jika penyajian sudah tepat berdasarkan kompetensi dasar serta kebutuhan siswa dalam bahan ajar dapat mempermudah pendidik dan siswa dalam proses pembelajaran. Penyajian materi dan tahapan pembelajaran menjadi dua hal pokok yang harus diperhatikan.

Pertama, pendahuluan merupakan bagian inti pembelajaran pada bahan ajar yang terdiri dari atas dua unit. Pada setiap unit terdiri atas dua bagian, yaitu apersepsi dan inti pembelajaran. Apersepsi bertujuan agar peserta didik termotivasi dan bersemangat sebelum belajar menulis cerpen bermuatan nilai karakter. Kedua, inti pembelajaran yang merupakan pokok-pokok materi, contoh, dan latihan yang dipelajari peserta didik selama proses pembelajaran berlangsung. Ketiga, penutup merupakan bagian akhir pada bahan ajar yang di dalamnya ada daftar pustaka yang berisi referensi yang dijadikan pedoman dalam 
penyusunan buku dan sampul belakang yang berisi deskripsi isi buku serta tujuan penggunaan buku ajar. Hasil penelitian pengembangan ditunjukkan dengan hasil uji validasi produk yang dilakukan untuk mengetahui nilai skor dan masukan atau saran untuk perbaikan produk. Hasil penilaian uji validasi produk berupa angka skor yang diberikan melalui angket instrumen sesuai aspek deskriptor. Uji validasi dilakukan uji ahli pembelajaran cerpen, ahli menulis kreatif cerpen, dan ahli praktisi.

Tabel 1. Hasil Uji Bahan Ajar Oleh Ahli Pembelajaran Cerpen

\begin{tabular}{|c|c|c|c|}
\hline No. & Aspek & $\mathbf{x}$ & $\mathbf{X i}$ \\
\hline 1. & Deskripsi isi & 25 & 28 \\
\hline 2. & Sistematika penyajian & 22 & 24 \\
\hline 3. & Bahasa & 18 & 20 \\
\hline \multirow[t]{4}{*}{4.} & Tampilan & 22 & 24 \\
\hline & $\sum \mathrm{x}$ & 87 & - \\
\hline & $\sum x \mathrm{i}$ & - & 96 \\
\hline & $\mathrm{P}$ & & \\
\hline
\end{tabular}

Keterangan:

$\sum \mathrm{x} \quad$ : Jumlah keseluruhan skor yang didapat

$\sum x i \quad$ : Jumlah keseluruhan skor ideal

$\mathrm{P} \quad$ : Presentase kelayakan

Berdasarkan tabel 1. dapat diketahui hasil uji bahan ajar ahli pembelajaran cerpen bahwa P memperoleh nilai 90,625 dan produk dinyatakan layak implementasi.

Tabel 2. Hasil Uji Bahan Ajar Oleh Ahli Menulis Kreatif Cerita Pendek

\begin{tabular}{|c|c|c|c|}
\hline No. & Aspek & $\mathbf{x}$ & $\mathbf{X i}$ \\
\hline 1. & Deskripsi isi & 27 & 28 \\
\hline 2. & Sistematika penyajian & 24 & 24 \\
\hline 3. & Bahasa & 17 & 20 \\
\hline \multirow[t]{5}{*}{4.} & Tampilan & 23 & 24 \\
\hline & $\sum \mathrm{x}$ & 91 & - \\
\hline & $\sum x i$ & - & 96 \\
\hline & $\mathrm{P}$ & 94,79 & \\
\hline & Tindak lanjut: Layak i & & \\
\hline
\end{tabular}

Keterangan:

$\sum \mathrm{x} \quad$ : Jumlah keseluruhan skor yang didapat

$\sum \mathrm{xi} \quad$ : Jumlah keseluruhan skor ideal

$\mathrm{P} \quad$ : Presentase kelayakan

Berdasarkan tabel 2. dapat diketahui hasil uji bahan ajar ahli menulis kreatif cerita pendek bahwa $\mathrm{P}$ memperoleh nilai 94,79 dan produk dinyatakan layak implementasi.

Tabel 3. Hasil Uji Bahan Ajar Oleh Praktisi/ Guru Bahasa Indonesia

\begin{tabular}{|c|c|c|c|}
\hline No. & Aspek & $\mathbf{x}$ & $\mathbf{X i}$ \\
\hline 1. & Deskripsi isi & 28 & 28 \\
\hline 2. & Sistematika penyajian & 24 & 24 \\
\hline 3. & Bahasa & 20 & 20 \\
\hline \multirow[t]{4}{*}{4.} & Tampilan & 23 & 24 \\
\hline & $\sum \mathrm{x}$ & 95 & - \\
\hline & $\sum x i$ & - & 96 \\
\hline & $\mathrm{P}$ & 98,95 & \\
\hline
\end{tabular}


Keterangan:

$\begin{array}{ll}\sum_{\mathrm{P}} \mathrm{x} & \text { : Jumlah keseluruhan skor yang didapat } \\ \mathrm{P} & \text { : Jumlah keseluruhan skor ideal dalam per-item } \\ & \text { Presentase kelayakan }\end{array}$

Berdasarkan tabel 3. dapat diketahui hasil uji bahan ajar ahli prkatisi/guru bahasa Indonesia bahwa P memperoleh nilai 98,95 dan produk dinyatakan layak implementasi.

Hasil uji keefektifan produk yang dilakukan dengan uji praeksperimen pretest-posttest pada tahap pelaksanaan dari hasil pretest sebelum produk diimplementasikan dengan hasil postest setelah produk diimplementasikan. Hasil uji keefektifan produk diuji dengan peneliti melakukan uji normalitas untuk mengetahui data terdistribusi normal menggunakan analisis One-Sample Kolmogorov-Smirnov Test hanya satu kelompok yaitu kelas XI Bahasa tanpa ada kelas kontrol.

Uji normalitas dilakukan dengan menggunakan One Sample Kolmogorof-Smirnov Test yang dasar pengambilan keputusannya, yaitu apabila nilai probabilitas (Asymp. Sig) >0,05 maka distribusi data normal. Hasil perhitungan uji normalitas data dari skor menulis peserta didik disimpulkan bahwa data terdistribusi secara normal karena data pretest dan postest memiliki data sig. $>0,05$. Data pretest didapat dengan sig. 0.665 dan postest didapat dengan sig. 0.319. Kedua, uji beda dilakukan setelah diketahui data terdistribusi secara normal. Uji beda dilaksanakan menggunakan teknik paired sample t-test (uji beda sampel berpasangan). Hasil perhitungan uji beda (uji t) dapat dilihat pada tabel 5.

Tabel 5. Hasil Statistik Uji Beda Sampel Berpasangan

Paired Samples Statistics

\begin{tabular}{|ll|l|r|r|r|}
\hline & & Mean & \multicolumn{1}{|c|}{ N } & Std. Deviation & Std. Error Mean \\
\hline Pair 1 & Pretest & 77.8947 & 19 & 5.84898 & 1.34185 \\
& Postest & 88.1579 & 19 & 4.77567 & 1.09561 \\
\hline
\end{tabular}

Paired Samples Test

\begin{tabular}{|c|c|c|c|c|c|c|c|c|}
\hline & \multicolumn{5}{|c|}{ Paired Differences } & \multirow[b]{3}{*}{$\mathrm{t}$} & \multirow[b]{3}{*}{$\mathrm{df}$} & \multirow{3}{*}{$\begin{array}{l}\text { Sig. (2- } \\
\text { tailed) }\end{array}$} \\
\hline & \multirow[b]{2}{*}{ Mean } & \multirow{2}{*}{$\begin{array}{c}\text { Std. } \\
\text { Deviation }\end{array}$} & \multirow{2}{*}{$\begin{array}{l}\text { Std. Error } \\
\text { Mean }\end{array}$} & \multicolumn{2}{|c|}{$\begin{array}{l}95 \% \text { Confidence } \\
\text { Interval of the } \\
\text { Difference }\end{array}$} & & & \\
\hline & & & & Lower & Upper & & & \\
\hline $\begin{array}{c}\text { Pair } 1 \text { Pretest - } \\
\text { Postest }\end{array}$ & $1.02632 \mathrm{E} 1$ & 4.55634 & 1.04530 & 12.45924 & $\begin{array}{r}8.0670 \\
7\end{array}$ & 9.818 & 18 & .000 \\
\hline
\end{tabular}

Berdasarkan hasil perhitungan uji beda dalam tabel 4.5, maka dapat diketahui bahwa $\mathrm{t}=-9.818$ dengan sig. 0.000 yang berarti $<0,05$. Sesuai dengan hasil yang didapatkan di atas, dapat disimpulkan bahwa nilai rata-rata pretest dan postest memiliki perbedaan secara signifikan. Rata-rata (mean) postest didapat 88.1579 dengan SD 4.77567 lebih tinggi daripada nilai rata pretest didapat 77.8947 dengan SD 5.84898. Data tersebut menggambarkan bahwa adanya peningkatan skor peserta didik dalam menciptakan sebuah karya tulis cerpen cerpen secara signifikan setelah memakai bahan ajar bermuatan nilai karakter dengan media film.

\section{PEMBAHASAN}

Bahan ajar yang berjudul Bahasa Indonesia: Film sebagai Penggugah Imajinasi Karya Cerpen Bermuatan Nilai Karakter untuk Mengembangkan Jati Diri ini digunakan sebagai buku pendamping untuk SMA kelas XI. Bahan ajar yang dikembangkan bermuatan nilai karakter. Adanya muatan nilai karakter dalam bahan ajar menulis cerpen diharapkan dapat meningkatkan dan menumbuhkan kesadaran peserta didik berkaitan dengan perilaku sebagai seorang penerus bangsa dan dapat mengimplementasikan nilai karakter tersebut.

Bahan ajar menulis cerpen ini disusun secara terstruktur dan bertahap. Hal ini disebabkan kegiatan pembelajaran diawali dengan pemahaman unsur cerpen dengan menggunakan teks dan media film Ketika pada unit 1 dan dilanjutkan dengan mencipta atau menulis cerpen dengan media film Aisyah Biarkan Kami Bersaudara pada unit 2, kegiatan tersebut dilakukan agar peserta didik tidak terlalu kesulitan dalam menulis cerpen bermuatan nilai karakter. 
Pada unit 1 peserta didik diberikan pemahaman mengenai unsur cerita pendek dengan pengayaan media film yang di dalamnya terdapat subpokok mengidentifikasi isi cerpen, menemukan tema, meneukan tokoh dan penokohan, menemukan alur dan latar cerpen, mengidentifikasi sudut pandang, dan mengidentifikasi gaya bahasa. Pada unit 2 peserta didik diberikan tugas untuk menulis cerita pendek bernilai karakter dengan media film yang di dalamnya terdapat subpokok mengembangkan tema cerpen bermuatan nilai karakter, menentukan tokoh (utama, tambahan, bawaan) penokohan (antagonis, protagonist, tritagonis), latar (tempat, suasana, dan waktu), sudut pandang, dan gaya bahasa, dan mengembangkan alur kemudian menulis cerpen secara utuh. Menulis tidak hanya menuangkan ide tetapi adanya proses penciptaan sehinggan menghasilkan sebuah tulisan (Mustafa \& Efendi, 2016). Selain itu, peserta didik juga dituntut untuk melakukan penilaian teman sejawat, menyunting dan merevisi kemudian memublikasikan cerpen bermuatan nilai karakter. Bahan ajar yang dihasilkan dari penelitian ini disusun berdasarkan empat kriteria kelayakan, yaitu deskripsi isi, sistematika penyajian, bahasa, dan tampilan. Berikut akan dipaparkan keempat kriteria kelayakan yang telah direvisi.

\section{Aspek Isi}

Bahan ajar yang direvisi dalam aspek ini terletak pada komponen kelengkapan materi pembelajaran keakuaratan materi. Pertama, kelengkapan materi. Revisi dilakukan dengan menambahkan konsep tentang struktur alur cerpen yang sebelumnya empat menjadi enam, yaitu pengenalan, konflik, komplikasi, klimaks, peleraian, dan penyelesaian. Konsep tentang jenis alur juga ditambahkan, yaitu alur maju, mundur, dan gabungan. Kedua, keakuratan materi. Revisi dilakukan dengan mengganti teks cerita pendek yang sebelumnya yang tidak mengandung nilai karakter toleransi antar umat beragama menjadi teks cerpen yang mengandung nilai karakter toleransi antar umat beragama pada contoh tahap mengembangkan alur. Hal tersebut memiliki tujuan agar siswa dapat terbantu untuk menyerap nilai karakter toleransi antar umat beragama sebelum menulis cerpen bernilai karakter.

\section{Aspek Penyajian}

Pada bagian ini yang direvisi adalah (1) langkah-langkah menulis cerita pendek, yakni mengembangkan tema, menentukan tokoh, menentukan penokohan/watak tokoh, menentukan latar, menetukan sudut pandang, serta menentukan gaya bahasa, mengembangkan alur. Sebelumnya tahap mengembangkan alur berada pada tahap kedua setelah menentukan tema. Perbaikan langkah-langkah menulis cerpen ini bertujuan untuk membantu sekaligus membimbing peserta didik dalam mencari ide menulis. (2) penambahan tugas/latihan dalam unsur gaya bahasa. Sebelumnya pada pemahaman konsep tentang gaya bahasa tidak terdapat tugas/latihan. Latihan pada setiap unsur bertujuan untuk menumbuhkan pemahaman mengenai apa yang dipelajari peserta didik.

\section{Aspek Kebahasaan}

Pada aspek bahasa, bahan ajar yang direvisi dari segi tata bahasa dan strukturnya, terdapat kata yang harus ditambah, diganti, maupun dihilangkan. Pertama, kata sapaan untuk peserta didik harus konsisten yakni menggunakan kata sapaan "kalian". Kedua, kata "disiplin" yang terdapat dalam contoh tema yang mengandung nilai karakter diubah menjadi "kedisiplinan".

\section{Aspek Tampilan}

Pada aspek tampilan bagian yang harus direvisi, yaitu terdapat gambar yang harus diganti karena tidak sesuai dengan konteksnya. Pada sampul bagian depan, kata film sebagai penggugah imajinasi, karya cerpen sebagai prestasi, dan karakter untuk mengembangkan jati diri diganti menjadi film sebagai penggugah imajinasi, karya cerpen bermuatan nilai karakter untuk mengembangkan jati diri.

\section{SIMPULAN}

Bahan ajar yang dibuat telah melalui uji kelayakan dan keefektifan. Pertama, hasil uji kelayakan produk diperoleh dari ahli pembelajaran cerpen, ahli menulis kreatif cerita pendek, dan praktisi/guru bahasa Indonesia diperoleh nilai rata-rata produk sebesar 94,78\%. Dengan demikian bahan ajar yang dikembangkan layak diimplementasikan. Kedua hasil uji keefektifan diketahui bahawa nilai $\mathrm{t}=-9.818$ dengan probabilitas 0.000 yang berarti $<0,05$. Sesuai dengan hasil tersebut, kesimpulannya adalah yakni ada perbedaan yang valid pada kemampuan menulis cerita pendek sesudah dan sebelum menggunakan bahan ajar bermuatan nilai karakter dengan media film. Oleh karena itu, bahan/buku ajar yang dikembangkan efektif untuk diimplementasikan dan dapat dijadikan buku pendamping dalam pembelajaran menulis cerpen.

Hasil uji kelayakan bahan/buku ajar menulis cerpen bermuatan nilai karakter layak untuk diimplementasikan. Namun, bahan ajar yang dikembangkan ini tentu mempunyai kelebihan dan kekurangan. Oleh sebab itu, terdapat saran-saran agar dapat diaplikasikan, diimplementasikan, dan dikembangkan (1) peserta didik, (2) guru, dan (3) peneliti lain. Berikut saran-saran bagi ketiga pihak tersebut. 
Pertama, bagi siswa. Bahan ajar dikembangkan dapat digunakan sebagai bahan pendamping dari buku pokok yang dipelajari di kelas. Bahan ajar digunakan untuk memudahkan siswa menulis cerpen. Selain itu, juga bisa mempelajari sendiri di rumah, ada atau tidak ada guru. Hal tersebut disebabkan dalam bahan ajar yang dikembangkan terdapat dua unit yang dapat membantu peserta didik menulis cerpen. Pada unit 1 peserta didik diberikan pemahaman mengenai unsur cerita pendek dengan pengayaan media film yang di dalamnya terdapat subpokok mengidentifikasi isi cerpen, menemukan tema, meneukan tokoh dan penokohan, menemukan alur dan latar cerpen, mengidentifikasi sudut pandang, dan mengidentifikasi gaya bahasa. Pada unit 2 peserta didik diberikan tugas untuk menulis cerita pendek bernilai karakter dengan media film yang di dalamnya terdapat subpokok mengembangkan tema cerpen bermuatan nilai karakter, menentukan tokoh, menentukan penokohan, menetukan latar, menentukan sudut pandang, dan menetukan gaya bahasa, dan mengembangkan alur kemudian menulis cerpen secara utuh.

Kedua, bagi guru. Buku ajar dikembangkan bisa digunakan pendidik sebagai referensi tambahan dalam pengajaran cerpen (materi, contoh, dan latihan), serta membantu mengarahkan aktivitas dalam pembelajaran sesuai dengan pendekatan yang digunakan dalam bahan ajar. Guru sekaligus bisa menanamkan nilai karakter dan berguna terhadap pengembangan jati diri peserta didik. Dengan demikian pembelajaran bahasa Indonesia tidak hanya belajar empat keterampilan berbahasa, melainkan juga belajar membentuk karakter peserta didik.

Ketiga, peneliti lain. Bahan ajar dikembangkan agar dapat dimanfaatkan oleh peneliti lain sebagai sumber ide dan rujukan dalam pengembangan bahan ajar, terutama jika peneliti lain tersebut juga akan mengembangkan topik tentang nilai karakter. Topik mengenai nilai karakter ini penting untuk terus dikembangkan agar akhlak para penerus bangsa tetap terjaga.

\section{DAFTAR RUJUKAN}

Aeni, E. S., \& Lestari, R. D. (2018). Penerapan Metode Mengikat Makna Dalam Pembelajaran Menulis Cerpen pada Mahasiswa IKIP Siliwangi Bandung. Semantik, 7(1), 1-15. DOI 10.22460/semantik.vXiX.XXX

Andayani, R., Pratiwi, Y., \& Priyatni, E. T. (2017). Pengembangan Modul Pembelajaran Menulis Cerpen Bermuatan Motivasi Berprestasi untuk Siswa Kelas XI SMA. BASINDO: Jurnal Kajian Bahasa, Sastra Indonesia, dan Pembelajarannya, 1(1), 103-116. https://doi.org/10.17977/um007v1i12017p103

Bird, C. (2001). Menulis dengan Emosi: Panduan Empatik Mengarang Fiksi. Bandung: Kaifa.

Dedy Herawan, K., \& Sudarsana, I. K. (2017). Relevansi Nilai Pendidikan Karakter Dalam Geguritan Suddhamala untuk Meningkatkan Mutu Pendidikan di Indonesia. Jurnal Penjaminan Mutu, 3(2), 223. https://doi.org/10.25078/jpm.v3i2.203

Dewi, A. M. S. (2013). Majalah Dinding sebagai Implementasi Kemampuan Menulis Cerpen Siswa yang Mengikuti Ektrakurikuler Jurnalistik di SMP N 4 Singaraja. Jurnal Pendidikan Bahasa dan Sastra Indonesia Undiksha, 1(1), 1-15.

Ghufron, A. (2010). Integrasi Nilai-Nilai Karakter Bangsa pada Kegiatan Pembelajaran. 12.

Kusumarini, R. (2013). Kemahiran Menulis Cerita Pendek dengan Mode Sugesti Imajinasi Media Lagu dan Video Klip Peserta Didik Berintelegensi Musik Tinggi dan Berintelegensi Musik Rendah SMA 1 Mejobo. Seloka: Jurnal Pendidikan Bahasa dan Sastra Indonesia, 2(1), 6.

Mubaroq, A. K., \& Subyantoro. (2017). Keefektifan Pembelajaran Menulis Cerpen dengan Model Sinektik dan Model KreatifProduktif pada Peserta Didik SMA Berdasarkan Tipe Pemerolehan Informasi. Seloka: Jurnal Pendidikan Bahasa dan Sastra Indonesia, 6(1), 53-58.

Mustafa, D. A. I., \& Efendi, A. (2016). Pengembangan Bahan Ajar Pembelajaran Menulis Cerita Berbasis Pendekatan Proses Bagi Siswa SMP. LingTera, 3(1), 1. https://doi.org/10.21831/1t.v3i1.8469

Ramdhani, M. A. (2014). Lingkungan Pendidikan dalam Implementasi Pendidikan Karakter. Jurnal Pendidikan Universitas Garut, 8(1), 28-37.

Romansyah, K. (2016). Pedoman Pemilihan dan Penyajian Bahan Ajar Mata Pelajaran Bahasa dan Sastra Indonesia. LOGIKA: Jurnal Ilmiah Lemlit Unswagati Cirebon, 17(2), 59-66.

Samani, \& Hariyanto. (2013). Konsep dan Model Pendidikan Karakter. Bandung: Remaja Rosdakarya.

Thiagarajaan. (1974). Instructional Development for Training Teachers of Exceptional Children: A Sourcebook. Indiana: University Bloomington.

Wahyuni, Hj. E. (2015). Meningkatkan Keterampilan Menulis Cerpen melalui Iklan Televisi pada Siswa Kelas IX-A SMP Negeri 3 Balikpapan. LINGUA: Journal of Language, Literature and Teaching, 12(2), 233-242. https://doi.org/10.30957/lingua.v12i2.38 